\title{
IMPLEMENTING ACTION RESEARCH IN A TEACHER PREPARATION PROGRAM: OPPORTUNITIES AND LIMITATIONS
}

\author{
Glenda L. Black \\ Nipissing University
}

\begin{abstract}
Action research has the potential to reconstruct schools into professional learning communities that are able to identify educational issues and develop appropriate solutions for $21^{\text {st }}$ century learning. Increasingly, teacher education programs are providing action research experiences to encourage analytical thinking and problem-solving skills (Darling-Hammond, 2009, 2012). The purpose of this study was to critically examine the experiences of the teacher educator and teacher candidates involved in the implementation of an action research component over four years in a revised consecutive initial teacher preparation program. A case study design using action research methodology was used in the research, which provided the tools to explore a complex phenomenon within its context: the implementation of an action research assignment in a core course in a teacher preparation program. The perceptions of the faculty teaching the course and the teacher candidates $(n=544)$ in each of the four years provided insight into challenges, benefits, and lessons learned. The discussion centers on the implementation of action research in a compulsory course in a teacher education program; identifying opportunities and limitations settled into four main categories: structural incongruence, reflection, growth, and recommendations.
\end{abstract}

KEY WoRDS: Action research; Teacher candidates; Teacher preparation program

\section{INTRODUCTION}

Research consistently identifies teachers as having the most influence on student improvement (McCaffrey et al., 2003; Rivkin et al., 2005; Rowan et al., 2002; Solheim et al., 2018). Scholarship advocates that in recent generations, this influence has become more complex, and will continue to be for those children entering kindergarten in 2020 (the youth of 2030). Aside from the transfer of knowledge, future teachers will need to prepare their students to "help shape a shared future built on the well-being of individuals, communities and the planet" (Organization for Economic Co-operation and Development, 2018, p. 3). To navigate this challenge, students will need to have the skills to be agents of change in a 
rapidly changing, globally interconnected, competitive, and technological world. Equipping teacher candidates entering the field with the skills to intentionally reflect on their praxis, specifically with the knowledge of action research methodology, will positively impact their future practice and student outcomes (Fichtman Dana \& Yendol-Hoppey, 2014; Goodnough, 2011; Savaskan, 2013).

Action research (AR) has the potential to reconstruct schools into professional learning communities that are able to identify educational issues and develop appropriate solutions for $21^{\text {st }}$ century learning. As a practical research approach to improving teaching and learning, AR emphasizes the teacher's "role as a reflective practitioner who is continually observant, thoughtful, and willing to examine personal actions in the light of the best possible practices" (Pelton, 2010, p. 5). Unlike fads in education, as an approach to professional development, AR never goes stale because the research is always relevant to the participants. There is an empowering, positive effect for teachers to research what is relevant to their own practice and to be more effective at what they are doing (Espositio \& Smith, 2006; Lankshear \& Knobel, 2004). AR centers on practitioners as teachers investigating areas of concern that are applicable to their practice. Developing the mindset and skills for AR is a form of "lifelong learning in the workplace after the course" (Ax et al., 2008). Increasingly, strong teacher education programs are providing AR and extensive field placement experiences to encourage analytical thinking and problem-solving skills (DarlingHammond, 2009, 2012; Ponte et al., 2004).

The aim of this study was to describe the practical experiences of a teacher educator and teacher candidates during the implementation of AR in a compulsory course in a teacher preparation program. More specifically, the research was guided by the following research questions:

- What challenges and benefits did a teacher educator encounter implementing an action research project for a course assignment?

$\circ$ What are the challenges and benefits teacher candidates encounter developing, implementing, and analyzing an action research assignment?

- How, if at all, did participation in the action research assist in developing teacher candidates into reflective practitioners?

This study covers four years of implementation of one course in a teacher preparation program at a university in Ontario. The discussion is not meant to be representative of Ontario teacher education in general, but to provide insights, examples, and lessons learned. This article starts with a description of the context of the study, a brief explanation of AR, and relevant literature is followed by a description of the research design. Descriptions of the results are followed by a discussion, in which themes of particular interest are examined.

\section{BACKGROUND To CONTEXT}

To assist in understanding the mechanisms necessary to support teacher candidates as teacher researchers, this article begins by contextualizing the research in an Ontario teacher preparation program. In response to provincial regulatory changes in 2014 , all consecutive 
teacher education programs were required to double their programs to two years (or foursemesters) and increase the number of field placement days to 80 (consecutive is a post undergraduate program). Further, mandatory core content related to teacher research was to be incorporated in the program. Specifically, the program must now include "how to use educational research and data analysis" and "how to use inquiry-based research, data and assessment and the selection and use of current instructional strategies to address student learning styles" (Ontario Ministry of Education [OME], 2014). The new content was to emphasize explicit integration of theory and practice and the use of research in teaching and learning (Ontario College of Teachers [OCT], 2017).

In the teacher preparation program of this study, the courses in the revised program were developed in collaboration with faculty committees: Core, Teachable, and Elective committees. All the courses in the program were 36-hour, 3 credit offerings. The original one year (or two-semester) program had one core curriculum course focused on lesson planning, assessment and evaluation, and classroom management. To meet the revised mandated curriculum, the Core committee designed three additional courses that were to be delivered in a series: 1) Introduction to Curriculum Design (focus: lesson planning and classroom management), 2) Assessment Evaluation and Communication of Student Learning (focus: assessment and evaluation and report cards), 3) Curriculum Design and Inquiry (focus: long-range planning and AR). The intent was to gradually build up teacher candidates' knowledge from basic lesson planning and reflection in Semester 1 to more advanced planning and development of teacher candidates' skills as teacher-researchers beginning in Semester 3.

Table 1 shows an overview of the courses included in the revised teacher preparation program. As can be seen, the Curriculum Design and Inquiry (CDI) course was scheduled for Semester 3 (Year 2, Fall) and was a new course to the program and the focus of this study. The Curriculum Design and Inquiry course introduced teacher candidates to AR. The goals of the course were for teacher candidates to explore of the principles of curriculum design and inquiry. Specifically, from the Program Learning Outcomes: "teacher candidates will demonstrate an ability to manage their own learning in changing circumstances and to select appropriate professional development opportunities to improve practice and enhance learning (i.e., through reflective practice and other research methods)” (Black, 2015, p. 2).

Table 1. Sample Teacher Preparation Program for Primary/Junior

\begin{tabular}{|c|c|c|}
\hline Semester & Course number & Course name \\
\hline \multirow[t]{6}{*}{$\begin{array}{l}\text { Semester } 1 \\
\text { (Year } 1 \text {, Fall) }\end{array}$} & EDUC 4736 & $\begin{array}{l}\text { Introduction to Curriculum Design and Teaching } \\
\text { (Core Course) }\end{array}$ \\
\hline & EDUC 4756 & Legal and Social Foundations \\
\hline & EDUC 4726 & Diversity and Inclusion \\
\hline & EDUC 4717 & Language and Literacy \\
\hline & EDUC 4737 & Health and Physical Education \\
\hline & EDUC 4714 & Practicum 1 (2 weeks) \\
\hline
\end{tabular}




\begin{tabular}{|c|c|c|}
\hline $\begin{array}{l}\text { Semester } 2 \\
\text { (Year } 1 \text {, }\end{array}$ & EDUC 4746 & $\begin{array}{l}\text { Assessment Evaluation and Communication of Student } \\
\text { Learning (Core Course) }\end{array}$ \\
\hline \multirow[t]{5}{*}{ Winter) } & EDUC 4766 & Technology Enriched Teaching and Learning \\
\hline & EDUC 4787 & Visual Arts \\
\hline & EDUC 4767 & Science \\
\hline & EDUC 4747 & Mathematics \\
\hline & EDUC 4714 & Practicum 1 (4 weeks) \\
\hline \multirow{5}{*}{$\begin{array}{l}\text { Semester 3, } \\
\text { (Year 2, Fall) }\end{array}$} & EDUC 4756 & Curriculum Design and Inquiry (Core Course) \\
\hline & EDUC 4776 & Special Needs of Students \\
\hline & EDUC 4757 & Music \\
\hline & EDUC 4777 & Social Studies \\
\hline & EDUC 4855 & $\begin{array}{l}\text { Practicum } 2 \text { (2016-1017: } 6 \text { weeks (including first } \\
\text { week of school); } 2018 \text { - } 5 \text { weeks (first week of school } \\
\text { moved to Year } 1 \text { ) }\end{array}$ \\
\hline \multirow[t]{3}{*}{$\begin{array}{l}\text { Semester } 4 \\
\text { (Year 2, } \\
\text { Winter) }\end{array}$} & EDUC 4727 & $\begin{array}{l}\text { Early and Emergent Literacy } \\
\text { Elective } 1 \\
\text { Elective } 2\end{array}$ \\
\hline & EDUC 4858 & Community Leadership Experience (2 weeks) \\
\hline & EDUC 4855 & Practicum 2 ( 6 weeks). \\
\hline
\end{tabular}

The 'inquiry' component of title of the course (Curriculum Design and Inquiry) could be interpreted as AR, self-study, narrative inquiry, or just reflection. It was left to the professor's discretion. As a teacher educator, I was assigned to teach the course and included an AR project as a course output, which is the foundation of the current study. Considering the time constraints of a 36-hour course, and the desire to align with the Ontario College of Teachers' Framework for the Teaching Profession (OCT, 2016), I chose to limit the focus only on AR. The course was developed with the assumption that conducting AR fostered valuable learning about oneself and a topic of interest (Davis et al., 2018; Mitchell et al., 2009) and developed more intentional reflection of one's praxis (Limbrick et al., 2010). Developing, implementing, and analyzing AR strengthens future teachers' professional practice (Goodnough, 2011). The purpose of the AR assignment was to provide teacher candidates with the experience of conducting research to inform their practice (Clark \& Fournillier, 2012) rather than to prove a claim. Transformation of schooling becomes the goal when teacher candidates develop the skills to conduct AR to systematically collect data to inform their practice (Cochran-Smith \& Lytle, 2009).

\section{CONTEXT IN THE LITERATURE \\ Action Research}

"We are convinced that the disposition to study ... the consequences of our own teaching is more likely to change and improve our practices than is reading about what someone else has discovered of his teaching." (Corey, 1953, p. 70)

Action research is an inquiry, undertaken with rigour and knowledge, so as to constantly refine praxis (Borg, 2010; Goodnough, 2011). The emerging evidence-based outcomes will 
then contribute to the research practitioner's continuing professional development (Koshy, 2005 , p. 2). For example, when AR is done by teachers, the practitioner is referred to as a practitioner-researcher, or and the research is practice-led or practice-based research. McNiff (2013) explains, "action research is a form of on-the-job research, undertaken by people in any context, regardless of their status, position, age or previous experience. It involves you thinking carefully about what you are doing, so it becomes critical self-reflective practice" (p. 23). Action researchers aim to understand their unique context and participants and choose to investigate based on their own concerns. The research is "intentional, thoughtfully planned, systematic, and methodical" and "starts with a research question and ends with the application of the knowledge gained that leads to new questions and a new cycle" (Efron \& Ravid, 2013, p. 7). The literature points to the benefits of teacher inquiry to inform and improve instruction that is cyclic, continuous (Ellis \& Castle, 2010; Navaneedhan, 2011), and learner centered (Timperley et al., 2009; Zeichner, 2010).

Scholars may not agree on the specific steps, stages, or phases of AR. However, they do agree that AR is dynamic, fluid, and at times messier than is implied in a linear description. The process has been described as cyclical (Efron \& Ravid, 2013; McNiff, 2013) or as a research helix (Kemmis \& McTaggart, 1988; Stringer, 2008). I used the following general principles for AR, as described by Efron and Ravid (2013) in my instruction to teacher candidates: 1) Identify an issue or problem the practitioner wants to explore, 2) Gather background information through a review of appropriate literature and existing research on the topic, 3) Design the study and plan the methods of collecting data, 4) Collect data, 5) Analyze and interpret data, and 6) write, share, and implement the findings (p. 23).

\section{Action Research in Teacher Education}

For almost two generations, AR has been promoted as an ideal design to be taught and utilized in teacher preparation programs. An indication of the relevance of AR in education is the proliferation of texts on the topic (Kitchen \& Stevens, 2008; Mitchell et al., 2009; Phillips \& Carr 2009). Action research is described as an approach to give teacher candidates an authentic assessment that allows them to act as professionals by identifying and finding solutions to issues within their own classrooms (Clarke \& Fournillier, 2012; Clayton \& Meadows, 2013; Cochran-Smith et al., 2009). Researchers point to the important role AR plays in the preparation of teacher candidates' professional development (Holter \& Frabutt, 2012; Perrett, 2003).

The cycle of inquiry allows teacher candidates to connect theory learned during coursework to their practical experience on their field placement, resulting in a meaningful experience (Clarke \& Fournillier, 2012; Carboni et al., 2007; Ulvik \& Riese, 2016). Engaging in AR allows teacher preparation programs to transform curriculums focused primarily on transmitting and memorizing information into a learning experience that engages teacher candidates in critical thought, research, inquiry, and independent leadership in the school community (Hagevik et al., 2012; Otto et al., 2009). Cochran-Smith and Lytle (2009) propose that providing teacher candidates the opportunity to design, implement, and analyze their action research project has the potential for them to become, "deliberative intellectuals, who participate in the joint construction of local knowledge, the questioning of common 
assumptions, and a thoughtful critique of the usefulness of research generated by others both inside and outside contexts of practice" (p. 2).

Although the literature strongly supports the implementation of an inquiry-based approach to systematically investigate one's practice with the aim of improving teaching and learning (Hopkins, 2008; McNiff, 2002), AR has been avoided in most teacher preparation programs. Reasons AR may be avoided include the rigid structures of most teacher education programs (Bond, 2013; Draper et al., 2011) or teacher educators, and the fact that mentor teachers and teacher candidates may be unfamiliar with the action research / inquiry design (Bryant \& Bates, 2010; Faikhamta \& Clarke, 2015). Some suggest that another potential barrier to using $\mathrm{AR}$ in teacher preparation programs is that conducting AR puts too much freedom in the hands of teacher candidates, such that inquiries may extend beyond the knowledge and/or experience of the course instructor (Ferreira \& Ryan, 2012; Zambo \& Zambo, 2007). Action research in a teacher preparation program may appear to be too much work and time to implement (Davis et al., 2018; Ponte et al., 2004). A limitation that restricts the potential for $\mathrm{AR}$ in the teacher preparation program is the short amount of time teacher candidates have to move through the development process (Bates, 2008; Dobber et al., 2012).

Ponte et al., (2004) point to limiting attitudes held by teacher candidates: viewing the link between theory and practice as irrelevant and the AR project onerous and time consuming. Some teacher candidates fail to see the natural connection between teaching and research/inquiry (Cochran-Smith \& Lytle, 2009). The notion inquiry as stance, a concept developed by Cochran-Smith and Lytle (2009), explored how teacher inquiry could be sustained and embedded as a professional learning practice to build local and relevant knowledge. Conversely, inquiry as project (Cochran-Smith \& Lytle, 2009) is time bound inquiry where participants make impulsive decisions and do not develop an interest in doing teacher inquiry in the future (Dobber et al., 2012). Although this research cannot predict graduating teacher candidates' propensity toward inquiry as stance, it can provide insight into the opportunities and limitations they experienced with AR as novice teachers. Considering the complexity of AR (e.g., participants, practice, theory), Luttenber et al. (2017) suggest teacher candidates reflect on the separate components to generate a whole knowledge base that informs practice.

\section{Reflection}

Fundamental to the action research process is the ability to intentionally and methodologically revisit, reflect on, and refine practice (Creswell \& Poth, 2018). Action research, in many ways, is simply formalizing the reflective process for teachers to systematically reflect on (analyze) carefully collected observations (data) that leads to action (Gillis \& Mitton-Kükner, 2019). The quality of educational experiences provided to students depends on the ability of teachers to stand back, reflect on their teaching practices, and strive to improve and make necessary changes through a process of self-reflection and selfevaluation. An impressive body of research supports reflective practice (Artzt \& ArmourThomas, 2002; Britzman, 1991; Darling-Hammond, 1996; Dewey, 1933; Griffiths, 2000; Luttenber et al., 2017; Margolis, 2002; Moore, 2002; Schön, 1983). Reflecting on practice is a strategy to self-evaluate and make judgments on knowledge, capacity, competence, and 
confidence as a teacher. According to Boyd and Fales (1983), "reflective learning is the process of internally examining and exploring an issue of concern, triggered by an experience, which creates and clarifies meaning in terms of self, and which results in a changed conceptual perspective" (p. 100). Teacher candidates' concerns tend to be related to self, tasks, situations, or impacts on students (Fuller \& Brown, 1975; Putney \& Broughton, 2010) that are activated during their mastery experience (i.e., their teaching field placement). Bandura (1986) supports self-reflection, as it positively contributes to altering a person's thinking and actions.

In their analysis of the literature, Atkins and Murphy (1993) reveal agreement among scholars that there are stages of reflection. However, the number of stages differs among models. For example, Mezirow (1981) identifies seven stages of reflection and Schön (1991) acknowledges only three. Atkins and Murphy (1993) discovered that all reflection models are hierarchical, but the differences are largely due to terminology. Their synthesis of the literature identified three stages of the reflective process: (a) The first stage "is triggered by an awareness of uncomfortable feelings and thoughts," (b) which is followed by "a critical analysis of feelings and knowledge," and then (c) the development of a "new perspective" on the situation (p. 1190). Further analysis and synthesis of the literature identified the cognitive and affective skills for critical reflection: description (recollect events accurately), critical analysis, self-awareness, synthesis, and evaluation (Atkins \& Murphy, 1993).

\section{METHOD}

A case study design was used in the research, which provided the tools to explore a complex phenomenon within its context. Miles and Huberman (1994) define case as, "a phenomenon of some sort occurring in a bounded context" and the case is the "unit of analysis" (p. 25). The phenomenon explored in this study was the implementation of an AR assignment in a core course in a teacher preparation program. Three weeks into teaching the course, I decided to undertake my own action research project connected to improving my teaching. As such, I was doing precisely what I was asking of the teacher candidates. In the subsequent years, my research was action research about action research (Smith \& Sela, 2005). By enacting an action researcher role, I was critically evaluating the implementation and outcomes of the action research project I had assigned; I was "walking the walk and talking the talk." The purpose of this study was to critically examine the experiences of the teacher educator (i.e., myself) and teacher candidates involved in the implementation of an AR component over four years in the revised consecutive teacher preparation program. The research explored the development of the course, benefits and challenges to teacher candidates conducting AR, revisions made over the four years of implementation, and proposed recommendations for future practice.

\section{Participants}

The participants are the year-two teacher candidates and myself, the teacher educator (i.e. course instructor). I had a role in the overall context, ranging from course development, implementation, and course revision. Although reflective practice and first-person action research refer to essentially the same process (Taylor et al., 2008), in reference to my positionality in the research, I functioned as an instrument of the research, while also 
working at removing bias through critical reflection and using a systematic approach to data collection and analysis (e.g., using member checking). Teacher candidates ( $n=544)$ in each of the four years participated in the study $(2016: n=71 ; 2017: n=170 ; 2018: n=165 ; 2019$ : $n=138$ ). Gaining insight into their perceptions was an important part of the research. Each class is made up of about 40 students. Teacher candidates are from all three teaching divisions (primary/junior: JK-Grade 6; junior/intermediate: Grade 4-10; intermediate/senior: Grade 7-12).

\section{Course DESCRIPTION}

Teacher candidates complete on-campus courses as well as field placements in each of the four semesters (see Table 1). Each class is 36 hours and is scheduled for two hours twice a week. In semester 1 , there are five courses and four weeks of field placement; in semester 2 , there are five courses and four weeks of field placement; in semester 3, there are five courses and five weeks of field placement; and in semester 4, there are three courses, two weeks (60 hours) of community service learning placement, and six weeks of field placement. The Curriculum Design and Inquiry course is in semester 3 (year 2, fall). In 2016 and 2017, a field placement was scheduled for the first week of school, followed by four weeks on campus, five weeks of field placement, and then back to campus for five weeks of classes. In 2018 and 2019 , the first week of school field placement was moved from year 2 to year 1 . This change was significant to the AR project and discussed in the results. Another meaningful factor was that three faculty members were teaching the same course in the first year of implementation (2016), each with different assignment expectations. In 2017 and 2018, only one faculty member was teaching the course. In 2019, two faculty members were teaching the same course and assigned the same assignment(s).

\section{Action Research Assignment}

In 2016, I had two assignments for the course: unit plan (40\%) and the AR project (60\%). Teacher candidates were offered the opportunity to revise and resubmit their assignments. However, an assignment worth $60 \%$ due at the end of the course was a concern for teacher candidates who had never done any type of research before. In 2017, although the AR assignment was still worth $60 \%$, I changed the structure of the assignment. The AR assignment was divided into Part A (30\%), which was to be completed before they left for their field placement, and Part B (30\%). Part A was returned immediately after they returned from their field placement. I also assigned 10\% for the certificate of completion, as proof of completing the Tri-Council Policy Statement: Ethical Conduct for Research Involving Humans Course on Research Ethics (TCPS 2: CORE) and the unit plan was changed to a longrange plan and was assigned $30 \%$.

When I initially implemented the AR assignment in 2016, all the components were submitted at the same time, including the introduction, description of the context, literature review, method, discussion of findings, implications, next steps, conclusion, and references. These components were given a word limit of approximately 4,000 words and were due at the end of the course. An PowerPoint presentation to share their project was also required. From 2017 onward, I reduced the word count to approximately 2,800 words and the assignment was divided into Part A (introduction, description of the context, literature review, method, 
and references), due prior to their five-week field placement, and Part B (abstract, method, discussion of findings, implications, next steps, conclusion, and PowerPoint showing components from Part A and Part B) was due the third week following their return to campus. Table 2 summarizes the Curriculum Design and Inquiry course schedule.

Table 2. Course Schedule of 'Curriculum Design and Inquiry'

\section{Timeline}

Week 1

Weeks 2-5

(Part A: introduction, description of the context, literature review, proposed method, references)

\section{Weeks 6-10}

(Collect data)

\section{Weeks 11-14}

(Part B: abstract, method, discussion of findings, implications, next steps, conclusion, and power point showing components from Part A and Part B)

* In 2016, the AR project was not divided into two parts. The entire project was due in Week 13 (Presentations Week)

\section{6*, 2017 2018, 2019 \\ Practicum On Campus \\ On Campus On Campus}

Practicum Practicum

On Campus $\quad$ On Campus

Course ethics approval from the university's research ethics board was required for each year for the AR assignment. Similar to an Honours Thesis course, I had to apply for ethics for the course. As part of the ethics protocol, I met with every teacher candidate before they submitted Part A of their AR and left for their field placement. All the teacher candidates verbally shared with me the purpose of their project, research question, and proposed method for collecting data. Based on these meetings, I could ensure each proposal was focused on practice, ethically appropriate, and manageable for the limited time for data collection. Signatures of approval for the AR were required from the principal and the candidate's mentor teacher. Depending on the AR, letters of approval from parents would also be required. Since the AR was implemented under the supervision of the classroom teacher and principal, individual board approval was not necessary.

Right from the start of implementing the AR project, a schedule for a round table style of presentations was created. The AR presentations were 20 minutes, and each teacher candidate was assigned a time and table to share their AR. The full presentation schedule and a timer were projected on a screen for all teacher candidates so that outside of their scheduled presentation time, they were free to join any presentation. Students were required to remain at the table for the full length of any presentation. Teacher candidates would share their AR using the PowerPoint they created by turning their laptop around to face the audience at the round table. Simultaneously across five or six tables, students were making presentations at the same time with about six people as their audience. The audience completed a peer feedback forms and one person from each table collected and handed them in. The forms were not intended to be included in their AR project mark, but rather to provide the presenter with feedback. 


\section{Data Collection}

Data collection over the course of four years included multiple sources to provide a comprehensive view of the case (AR implementation), which enhances the data's credibility (Yin, 2014). Understanding participants' perspectives was done through analysis of their personal narratives or stories (Lather, 1992). Data included policy documents, external reviewers' reports, and the instructor's field notes from a reflective journal maintained during the four years of the AR assignment's implementation. Data was collected from 544 teacher candidates in the form of informal interviews, written reflections, course evaluations, the completed AR reports and presentations, and presentation feedback forms. The informal interviews were individual conversations with all teacher candidates about their proposed AR, and casual conversations throughout the AR implementation, analysis, and presentations. Data also comprised the written reflections that were part of students' final AR report, and a consolidation class activity where students recorded the benefits and challenges to AR. Last, written course evaluations (i.e., standard university Student Opinion Surveys and comments) were also taken into consideration.

\section{Data Analysis}

Data collection began three weeks into the first course with field notes in the form of a personal journal (in Word). Any hard copy data collected from teacher candidates was converted to digital files. Each type of data was organized into folders for each year (e.g., AR assignments, Student Opinion Surveys, consolidation reflections). Data were analyzed at the end of each course/year. Following AR methodology, I engaged in critical reflection, "a form of on-the-job research" (McNiff, 2013, p. 23), to inform how to improve the implementation of the AR assignment for the next year. At the end of the fourth year the data from all four years was compiled.

Methods of analysis for the study included three streams of activity identified by Miles and Huberman (1994): data reduction, data display, and conclusion drawing/verification. Deriving categories and themes, then subsequently drawing conclusions with regard to the major research, proceeded primarily from the various data displays. Verification involved constant comparison of the data sources to test the trustworthiness of the results (Glaser \& Strauss, 1967; Handsfield, 2006). The analysis began with searching for, identifying, and summarizing themes in the field notes, research context, informal interviews, written reflections, course evaluations, assignment reports and presentations, and external reviewers' reports. The list of codes began with the literature, and included the challenges and benefits to implementing AR in teacher preparation programs, and teacher candidates as reflective practitioners, and more codes emerged through the analysis.

\section{RESULTS}

The results are presented in relation to the research questions. Pseudonyms are used in place of all the names of the participants. 


\section{Challenges for Teacher Educator and Teacher Candidates Implementing AR}

Addressing the first research question, the challenges for the teacher educator and teacher candidates are organized into themes involved in the implementation of the action research project.

\section{University Research Ethics Board}

The AR project as an assignment in the Curriculum Design and Inquiry (CDI) course was new to the program and was under a great deal of scrutiny from the university's research ethics board (REB). The REB routinely processed Honours courses, which included a research component. However, in the first year, some members of the REB were confused about action research methodology and how this design was connected to a teaching field placement. The misunderstanding was due to the assumption that teacher candidates would be recruiting participants. Meeting the committee in person assisted in clarifying the design. In the second year, I was under pressure to modify the AR assignment and limit the type and scope of projects in which the teacher candidates could engage. Again, a meeting with the REB committee where I shared the types of AR projects the teacher candidates proposed to implement facilitated the approval process. Although renewal for the AR was required for the third and fourth year, the chair of the REB was the same person for years 2-4, which led to only minor clarifications required to the protocol.

\section{Teacher Preparation Program}

Faculty. Faculty were mixed on their level of support for the action research approach to developing teacher candidates' reflective practice and ongoing professional development. Support for AR in the teacher preparation program was on a continuum from fully supportive, to wanting teacher candidates to use a phenomenological or a more traditional approach to research, to wanting no research component at all. In the first year of implementation, three faculty were assigned the same course and all three assigned different assignments, creating inconsistency in expectations for the same course. Some faculty perceived the AR component was granted special privileges, as teacher candidates were expected to collect data while on placement. Assigning work during placement is discouraged in the program. To address the concern of additional work in subsequent years, I strongly encouraged teacher candidates to focus their research on something related to or embedded into their practice - not an additional component or added layer of work. The systematic collection of data was to inform their practice.

Practicum Schedule. In the first and second year of implementation, the Year 2 teacher candidates attended a week of field placement in the first week of the school year. This week was considered an opportunity for teacher candidates to observe the entry protocol and practices at the start of the school year and to discuss potential AR topics with their mentor teacher. During this week, the teacher candidates also had the opportunity to meet the students in their field placement and familiarize themselves with the context (i.e., physical classroom) for their AR project. In the third year of this project, the first week field placement was moved to Year 1 . The reason for this change was to allow Year 1 teacher candidates initial experience in a classroom. Support for keeping the first week of field placement in Year 2 was almost split down the middle with faculty. 
In the first two years $(2016,2017)$ of implementation, many of the teacher candidates collaborated with their mentor teachers on their AR projects to develop meaningful inquiries. For the third and fourth year of implementation $(2018,2019)$, teacher candidates were mostly unable to meet with their mentor teacher and students until they arrived for their first day of field placement. For many teacher candidates who were unable to contact their mentor teachers in advance of their placement to discuss the AR project, they planned an AR that could be applicable to any class context. This shift in planning a project within a specific familiar context to planning a project for a generic group of students affected the diversity and utility of the AR projects. Further, in the first two years, many mentor teachers and teacher candidates planned a collaborative AR project in the first week of school. In subsequent years, there were few collaborative AR projects, as many teacher candidates were not able to communicate with their mentor teacher in advance of their placement.

\section{Implementation of the Action Research}

In the first year of implementation (2016), teacher candidates' perceptions were mixed. Some valued the experience of immersing themselves in the teacher-researcher role (further discussed below in the benefits section); others were strongly opposed to the AR project. The negative opinions about the assignment were expressed by 10 (of the 71) teacher candidates. The comments in class and in the course evaluations related directly to the inconsistency in assignment expectations across the classes among the three faculty members. For example, 2016 course evaluation comments included: "Would have been better if the assignments were the same across all divisions and teachers" and "The differences between different course sections was questionable." The perceived extra effort for an AR project compared to the required assignments in the other classes was viewed unfavourably. Five teacher candidates suggested AR would be more appropriate for a master's program. Interestingly, three of the teacher candidates who felt that AR should be in the graduate program also noted in their 2016 course evaluation that they benefited from the experience. For example, "The action research project was a good idea; however, it was too much. I really enjoyed reflecting on my teaching and found this will help me in the future. The assignment would be better suited for a master's level program." In 2017, only one teacher candidate of 170 recommended the AR would be better suited to a master's program. In 2018 and 2019 no such comments were put forward.

\section{Mentor Teachers}

For the first and second year of implementation, an email message was sent by the field placement office on behalf of the teacher educator informing the mentor teachers that teacher candidates would be talking to them about their AR assignment. However, mentor teachers have varying degrees of experience with AR. For many teacher candidates in the first cohort (2016), conversations with their mentor teachers about AR were not helpful because the mentor teachers were not familiar with AR methodology. The comments by a few mentor teachers to the teacher candidates were less than encouraging: "This is your assignment to do." Other negative comments focused on what was expected of them as mentor teachers, as well as how this "experience in the classroom would take away from planning time for lessons." For many, the mentor teachers were undecided about the 
assignment. For example, a teacher candidate commented, "My mentor teacher didn't really know what AR was when I first brought it up. When I started to explain it and look at the articles together, he was pretty neutral about it, but was still supportive of what I wanted to do." Some mentor teachers who were ambivalent about the AR projects were "unfamiliar with action research, but liked the idea of it and [were] interested in seeing the end results." Nevertheless, for as many mentor teachers who were indifferent, there were teachers who were encouraging and supportive, which will be discussed further in the benefits section.

\section{School Administration}

A protocol for the university ethics requires teacher candidates confirm approval from the school administration and mentor teachers. In four years of implementing the AR project, only four administrators required teacher candidates to apply for ethics approval to the school board ethics committee. In each of these situations the administrator was new to the position and was not familiar with AR. Further, the program in the current study partners with 54 of the 72 school districts in the province. Each of the school districts has their own ethics protocol and many approve submissions only a few times a year. Teacher candidates submitting individual applications would not be processed until after the course ended. In each of the four cases, as per the teacher educator's instructions, an alternative approach to the assignment was outlined.

\section{Time}

Teacher Educator. Creating and planning an inquiry opportunity for teacher candidates within the strict teacher preparation program schedule was challenging. Further, considerable time was necessary to introduce AR as a methodology for inquiry, review all the components of AR, meet individually with all the teacher candidates to discuss their proposed AR, and grade and provide descriptive feedback for the individual AR assignments (for Part A, then again for Part B); there were 544 action research projects over four years.

Teacher Candidates. The most consistent perceived challenge for teacher candidates was time, and, as a consequence, AR increased their stress. In reflections, most teacher candidates reported that a challenge in AR was, "time - to plan, to reflect, and analyze and produce sharable results." Similarly, "the challenges of implementing the action research process [come] from a decreased ability to collect data when you are actually teaching. It is hard to do both well and effectively." Field placements are evaluated by their mentor teacher and university faculty facilitator. The teacher candidates viewed the AR as an added layer of work, instead of using it as a strategy to inform their practice. However, teacher candidates claimed that time was a factor in all aspects of the program.

\section{Benefits for Teacher Educator and Teacher Candidates with Implementation of AR Teacher Preparation Program}

Most faculty supported the notion of AR in the teacher preparation program. Some faculty expressed interest in collaborating on the AR project. Faculty teaching specific subjects, for example were interested in considering how they might incorporate the assignment. A few faculty members were assigning an inquiry type of assignment for their courses, to be implemented while they are on placement. In 2019, another faculty member was assigned 
to teach the CDI course and was open to the idea of approaching the AR assignment. At the end of the term, the faculty member expressed enthusiasm for teaching the course again with the AR assignment. In 2020, a third faculty member began teaching the course and was agreeable to do the same.

Recently, the teacher preparation program has gone through two external review processes for accreditation. Both anecdotal and recorded comments in the report from reviewers were favourable for the inclusion of AR in the teacher preparation program. Positive anecdotal comments coming directly from a reviewer from one of the accreditation agencies noted that in interviews with the teacher candidates, they described the AR process in detail with excitement and pride.

\section{Acceptance for Action Research}

Evidence for the positive impact of the AR was in the course evaluations, field notes, informal interviews, written reflections, AR reports and presentations, and the increased interest in applying for graduate studies. After the first year of implementation, only one teacher candidate made a comment in the course evaluations that the AR project was an assignment better suited for a master's program. All other course evaluations were positive. One response was: "The CDI course was everything - the challenge, the AR project, expectations - this is why I came to this university." Another teacher candidate commented, "The AR project was the absolute best part of this whole program and help me feel like I was actually earning my degree."

A few changes were made after the first year. The weighting of the assignments was redistributed to address teacher candidates' concern about the assignment being worth $60 \%$. Although the AR project was still worth $60 \%$ of the final mark, it was divided into a Part A (30\%) and Part B (30\%). Part A included the introduction, description of the context, literature review, method, references, and PowerPoint of the components, and Part B included: abstract, method, discussion of findings, implications, next steps, conclusion, and power point showing components from Part A and Part B. Also, 10\% was allotted to the completion of the ethics tutorial. For some teacher candidates, this was a gift as they had completed the ethics tutorial for a previous course (undergraduate or graduate). Another revision after the first year was the reduction of approximate words for the assignment to address concerns that the assignment was too long. Interestingly, the written assignments were not shorter in length. Rather, concerns were always raised about going over the word limit.

After grading the first set of AR projects, it was obvious that teacher candidates had various levels of experience with writing essays and reports, and using APA. I created a template for the AR assignment (in APA format) - one for Part A and Part B. The template included all headings and subheadings, approximate word count for each section, a brief description for each section (from a checklist from the assignment description), and sample APA references. When introduced, the template was greeted with a mix of relief and giggles. Relief from those who were concerned about the APA formatting and giggles from those who were experts in academic writing. Ninety-five percent of the AR projects submitted and presented were 
exceptional in their effort and passion for their topic, and demonstrated commitment to improving their knowledge and practice. Only five percent of the teacher candidates developed an AR deemed acceptable (not exceptional). For the most part, these 5\% of teacher candidates were also experiencing difficulty in other areas of the program. By developing the teacher candidates' basic research skills, and by providing the assignment template, the AR project was better received.

\section{Peer Support}

For some teacher candidates, coming up with a topic for their inquiry was daunting. Sharing a list of AR titles from previous years helped to alleviate concerns. Initially, teacher candidates were concerned about presenting their AR to their peers. However, every year after the first set of round table presentations, a visible calm settled over the room. Evidence of their interest in their peers' presentations was the absence of personal devices during the presentations. Only the presenters' laptops were on the tables, and rarely was a cell phone out during presentations. Peer assessments were overwhelmingly positive for the individual presentations.

\section{Mentor Teachers}

Although some mentor teachers were indifferent toward the AR project, many mentor teachers were excited about collaborating with the teacher candidates on an inquiry. Teacher candidates shared their mentor teachers' reactions to the AR, for example: "My mentor teacher loved the idea and even made suggestions to make it better and more relatable to the students." Another teacher candidate reported their mentor teacher's response: “'Cool! That's great! Do you have any ideas?' We discussed our ideas together and came up with our favourite that was beneficial to both teacher and students and began developing a research plan and resources. She was extremely supportive and encouraging." Teacher candidates shared how their mentor teacher provided support and feedback on how to continue the cycle of inquiry. As an example, one teacher candidate's inquiry was to increase students' verbal communication in French by having students share their work in small groups. Focusing on the students who rarely spoke in large group discussions, he tracked the frequency of their participation in small groups. In a discussion about the data collected, the mentor teacher challenged the teacher candidate to inquire further by exploring the accuracy of the French communication. Another teacher candidate was contacted by the principal to come back to the school and share her findings on cell phone management strategies with the school staff.

\section{Teacher Candidates as Reflective Practitioners}

The third research question concerned whether participation in an AR project impacted teacher candidates' development as reflective practitioners. Considering the factors that influence teacher candidates' knowledge, skills, and professional development, there is no way to claim the AR was solely responsible for enhancing teacher candidates' reflective practice. Nevertheless, teacher candidates' course evaluations, written reflections on the AR process, and written reports reveal substantial connection between AR and reflective and improved practice. In the student evaluations, one comment stated: "Although the action research was stressful to complete among all the chaos of the field placement, it really put 
things into perspective and help me to reflect on myself." Another teacher candidate stated, "The action research project was the best option for a final project. I appreciated its value in my reflective practice development." Another shared, "AR allowed me to critically think about my students needs and how I can do my best to meet them." They understood AR methodology was designed to answer the question: How well are my students' learning and progressing toward the learning goal?

Teacher candidates' AR topics reflected where they were in their teacher development; at that moment, for that field placement experience. Their concerns are related to self, tasks, situations, or impacts on students (Fuller \& Brown, 1975; Putney \& Broughton, 2010). Samples of AR titles for teacher candidates who were concerned about self include: Teacher Candidate Anxiety, Self-Efficacy, Reflective Practice; Critical Reflection as a Means of Building Self Efficacy: A Teacher Candidate Perspective; Impacts of Mindfulness Practices on Teacher Wellbeing; Implementing Pedagogical Documentation to Inform Teaching Practice and Improve Student Learning.

The next level of teacher development (Fuller \& Brown, 1975; Putney \& Broughton, 2010) moves from the self/teacher to tasks engaging the students' learning. Teacher candidates' AR explored tasks (i.e., what students are doing) such as: Debates in the Classroom; Number Talks and Number Strings: Welcome to the Ground Floor; Increasing Student Engagement in Intermediate Mathematics Through Gamification. The next level of development is the focus on students. Examples of AR projects focused on enhancing students' self-regulation and academic improvement included: The Effects of Meditation on Student Productivity and Performance Anxiety; The Influence of Exit Tickets to Help Differentiate Instruction to Meet the Diverse Needs of Learners; The Effects of Brain-Breaks in the Classroom to Help with Off Task Behaviour; Co-Creating Self-Evaluations in Physical Education.

\section{DisCuSSION}

This discussion speak directly to the call from researchers to explore action research in teacher preparation programs (Davis et al., 2018; Ulvik \& Riese, 2016). The results from this project will be summarized and juxtaposed with the existing literature. The discussion relates to the research questions, and stems from the described practical experience of a teacher educator and teacher candidates involved in implementing AR in a compulsory course in a teacher education program. Opportunities and limitations are described through four main categories: structural incongruence, reflection, growth, and recommendations.

\section{Structural Incongruence}

The results from this study and the literature underscores resistance from stakeholders for the implementation of AR in teacher preparation programs. Aligning with the literature (Bond, 2013; Draper et al., 2011), the rigid structure of the teacher preparation program created challenges with scheduling the field placement to facilitate the AR process. Similar to previous research (Bryant \& Bates, 2010; Faikhamta \& Clarke, 2015), some university administration, faculty, and mentor teachers were not familiar with AR design, which created misunderstandings (e.g., viewing AR as traditional research). A challenge for almost anything related to education is time and the incorporation of AR in this program was no exception 
(Bates, 2008; Dobber et al., 2012). The length of the program is also a serious constraint. Requirements to comply with the many regulatory aspects that teachers require means that time for teacher as researcher is limited. Implementing an entire AR project over the course of one semester moved teacher candidates through the process at a rate which did not allow for them to respond "to new questions and a new cycle" (Efron \& Ravid, 2013, p. 7). And a few teacher candidates each year failed to see the connection between theory and practice (Luttenber et al., 2017).

\section{Reflection}

Teacher candidates were using the data to inform their decisions. The results from their AR provided evidence that their efforts were making a difference. For example, one teacher candidate implemented a rewards system to improve students' behavior and engagement in class. Reflecting on her AR inquiry, she said she would never implement a similar reward system in her own classroom. Congruent with the literature (Creswell \& Poth, 2018), the AR process provided teacher candidates opportunities to reflect on, revise, and strengthen their practice. Understanding, through reflection, allowed teacher candidates to focus on a topic that was of interest to them and aligned with where they were in their teacher development (Fuller \& Brown, 1975; Putney \& Broughton, 2010). The energy, excitement, and pride that these teacher candidates demonstrated while engaging in AR makes it more likely that a new generation of teachers will bring this reflective learning practice into the classrooms and schools to prepare $21^{\text {st }}$ century learners.

\section{Growth}

Aligning with the literature (Davis et al., 2018; Mitchell et al., 2009), most of the 544 teacher candidates appreciated and valued the opportunity to dig deeper into a topic of their interest. Despite the challenges, teacher candidates developed, implemented, and analyzed an inquiry of their interest and engaged in deliberate and intentional reflection on their practice as educators (Limbrick et al., 2010). Teacher candidates understood that answering one question leads to new questions and a new cycle of inquiry (Efron \& Ravid, 2013). What was most obvious in the data was the pride of teacher candidates in their AR. Although they started the AR journey concerned they would not be able to achieve their goals, they were bursting with pride, self-confidence, and enthusiasm, and they appreciated sharing their results with their peers and in the school communities.

\section{Recommendations}

The following recommendations are based on the findings from this study and the literature.

\section{Teacher Preparation Programs}

Support for AR is trending upwards, as reflected in the support that spans institutional levels (OCT, 2016; OME, 2020) and collective bargaining units (e.g., the Elementary Teacher Federation of Ontario) (Flynn, 2016), and this further illustrates the need for teacher preparation programs to prepare novice teachers with the knowledge, skills, and experience with teacher-researcher professional development. However, the volume of learning involved in teacher education is a challenge to systemic change. Taking the time to overcome resistance from faculty begins with a discussion of how AR fits in the program for teacher 
candidates' professional development and future practice. Specifically, there needs to be a "reculturing" (Louis, 2008) among leadership, faculty, and mentor teachers towards a shared vision, and a collective commitment to the goals of AR and its value to teacher candidates' understanding the process and practice of AR (Davis et al., 2018). Internal research ethics boards are familiar with traditional research methodologies. Engaging members of the REB up front will help them to understand AR.

Consider the time allotted within the program to support teacher candidates' AR. The timing worked well in my first two years of implementation. Teacher candidates were on placement the first week of school and were able to discuss an AR proposal with their mentor teacher. With my support, they developed the AR proposal on campus, collected data for the AR project during their five-week placement, and came back to campus and analyzed the data and presented their AR (see Table 2). Teacher candidates come into the program with varying degrees of research experience. To secure a positive experience, provide multiple opportunities for peer support and exchange of ideas. Assist teacher candidates to see the relevance of AR to improve their practice. Scaffold learning to ensure teacher candidates have the capacity to study themselves. For example, create capacity to do the AR by breaking it down into manageable pieces. More effective communication is needed between teacher preparation programs and mentor teachers to enhance their understanding of their role in the AR project. Mentor teachers vary in their use of informal and formal AR in their classroom, from no use at all to ongoing. Making resources available for mentor teachers could enhance their understanding of AR and how they might assist teacher candidates' development of the AR process.

\section{Future Research}

Findings of this research are consistent with the literature. However, this study is unique in that the exploration was over four years, including the implementation and a large sample size. More studies are needed to unwrap the layers of complexities to this type of initiative. For three of the four years, I was the sole faculty member implementing the AR component. Collaborating with colleagues to examine the impact of AR could be explored. For the past three years, my final words to teacher candidates include a request that they e-mail me to share how they, as teachers, are using AR. Future studies could follow-up on how teachers (former teacher candidates) adapt an inquiry/researcher mindset, or whether an inquiry stance evolves or changes over time (Cochran-Smith \& Lytle, 2009; Davis et al., 2018). I could also follow up with some of the former teacher candidates in five years for a check in.

\section{CONCLUSION}

There will always be new challenges in education. Teacher preparation programs are an ideal time to teach early career teachers research skills and develop an orientation towards a teacher-researcher mindset (Davis et al., 2018). Equipped with the understanding of how to identify a problem, develop a plan, and systematically collect and analyze data will empower teachers to be agents of change and to meet the challenges of teaching for $21^{\text {st }}$ century deep learning competencies (Fullan \& Scott, 2014). A caution for the implementation of AR is that the inquiry should not be a top-down initiative, where the decision is made for the teacher candidates about what they can explore. A teacher candidate described AR, as 
"the fuel for fire and the spark is the beginning idea of change." Action research is not a trendy or fad program or legislated mandate. A virtue of action research is that it is a professional development process that leads to effective and focused response to student improvement, and though teacher candidates may initially resist, on reflection they will recognize and appreciate their growth for achieving their goals.

\section{REFERENCES}

Artzt, A. F., \& Amour-Thomas, E. (2002). Becoming a reflective mathematics teacher: A guide for observations and self-assessment. Lawrence Erlbaum Associates.

Black, G. L. (2015). Developing teacher candidates' self-efficacy through reflection and supervising teacher support. In-Education. 21(1), 78-98.

Ax, J., Ponte, P., \& Brouwer, N. (2008). Action research in initial teacher education: An explorative study. Educational Action Research, 16(1), 55-72.

Atkins, S., \& Murphy, K. (1993). Reflection: A review of the literature. Journal of Advanced Nursing,18(8), 1188-1192. https://doi.org/10.1046/j.1365-2648.1993.18081188.x

Bandura, A. (1986). Social foundations of thought and action: A social cognitive theory. Prentice Hall.

Bates, M. (2008). The responsive case study: Action research and action learning in short courses. Educational action research, 16(1), 97-108.

Bond, N. (2013). Developing a professional learning community among preservice teachers. Current Issues in Education, 16(2), 1-16.

Borg, S. (2010). Language teacher research engagement. Language Teaching, 43(4), 391429. http://doi.org/10.1017/S0261444810000170

Boyd, E. M., \& Fales, A. W. (1983). Reflective learning key to learning from experience.Journal of Humanistic Psychology, 23(2), 99-117.

Britzman, D. P. (1991). Practice makes practice: A critical study of learning to teach. State University of New York Press.

Bryant, J., \& Bates, A. (2010). The power of student resistance in action research: Teacher educators respond to classroom challenges. Educational Action Research, 18(3), 305318. 
Carboni, L. W., Wynn, S. R., \& McGuire, C. M. (2007). Action research with undergraduate preservice teachers: Emerging/merging voices. Action in Teacher Education, 29(3), 50-59.

Corey, S. M. (1953). Action research to improve school practices. Teachers College Press.

Clarke, P. A., \& Fournillier, J. B. (2012). Action research, pedagogy, and activity theory: Tools facilitating two instructors' interpretations of the professional development of four preservice teachers. Teaching and Teacher Education: An International Journal of Research and Studies, 28(5), 649-660.

Clayton, C. \& Meadows, G. (2013). Action research projects in pre-service teacher education. Teacher Educators' Journal, 20, 5-18.

Cochran-Smith, M., Barnatt, J., Friedman, A., \& Pine, G. (2009). Inquiry on inquiry: Practitioner research and student learning. Action in Teacher Education, 31(2), 1732.

Cochran-Smith, M., \& Lytle, S. L. (2009). Inquiry as stance: Practitioner research for the next generation. Teachers College Press.

Creswell, J. W., \& Poth, C. N. (2018). Qualitative inquiry: Choosing among the five approaches (4th ed.). Sage.

Darling-Hammond, L. (1996). The quiet revolution: Rethinking teacher development. Educational Leadership, 53(6), 4-10.

Darling-Hammond, L. (2009). Teacher education and the American future. Journal of Teacher Education, 61(1-2), 35-47. https://doi.org/10.1177/0022487109348024

Darling-Hammond, L. (2012). Powerful teacher education: Lessons from exemplary programs. John Wiley \& Sons.

Davis, J., Clayton, C., \& Broome, J. (2018). Thinking like researchers: Action research and its impact on novice teachers' thinking. Educational Action Research, 26(1), 59-74. https://doi.org/10.1080/09650792.2017.1284012

Dewey, J. (1933). How we think: A restatement of the relation of reflective thinking to the educative process. Henry Regnery Co.

Dobber, M., Akkerman, S. F., Verloop, N., \& Vermunt, J. D. (2012). Student teachers' collaborative research: Small scale research projects during teacher education. Teaching and Teacher Education, 28(4), 609-617. 
Draper, R. J., Adair, M., Broomhead, P., Gray, S., Grierson, S., Hendrickson, S., Jensen, A.P., Nokes, J.D., Shumway, S., Siebert, D., \& Wright, G. (2011). Seeking renewal, finding community: Participatory action research in teacher education. Teacher Development, 15(1), 1-18

Efron, S., \& Ravid, R. (2013). Action research in education: A practical guide. Guilford Press.

Ellis, C., \& Castle, K. (2010). Teacher research as continuous process improvement. Quality Assurance in Education, 18(4), 271-285. http://doi.org/10.1108/0968488 1011079134

Esposito, J., \& Smith, S. (2006). From reluctant teacher to empowered teacher-researcher: One educator's journey toward action research. Teacher Education Quarterly, 33(3), 45-60.

Faikhamta, C., \& Clarke, A. (2015). Thai pre-service science teachers engaging action research during their fifth year internship. Asia Pacific Journal of Education, 35(2), 259-273.

Ferreira, J., \& Ryan, E. (2012). Working the system: A model for system-wide change in preservice teacher education. Australian Journal of Teacher Education, 37(12).

Fichtman Dana, N., \& Yendol-Hoppey, D. (2014). The reflective educator's guide to classroom research: Learning to teach and teaching to learn through practitioner inquiry ( $3^{\text {rd }} \mathrm{ed}$.). Corwin Press.

Flynn, T. (2016). Learning through teacher research: A guidebook for your action research journey. Elementary Teachers' Federation of Ontario.

Fullan, M., \& Scott, G. (2014). New pedagogies for deep learning whitepaper: Education PLUS. Collaborative Impact SPC.

Fuller, F. F., \& Brown, O. H. (1975). Becoming a teacher. In K. Ryan (Ed.), Teacher education: $74^{\text {th }}$ yearbook of the National Society of Education (pp. 25-52). University of Chicago Press.

Gillis, E., \& Mitton-Kükner, J. (2019). Exploring teachers' experiences of participating in teacher inquiry as professional learning. Education, 25(1), 19-33.

Glaser, B., \& Strauss, A. (1967). The discovery of grounded theory: Strategies for qualitative research. Aldine Publishing Company.

Goodnough, K. (2011). Examining the long-term impact of collaborative action research on teacher identity and practice: The perceptions of K-12 Teachers. Educational Action Research 19(1), 73-86. 
Griffiths, V. (2020). The reflective dimension in teacher education. International Journal of Educational Research, 33(5), 539-555. https://doi:10.1016/S0883-0355(00)000331

Handsfield, L. (2006). Being and becoming American: Triangulating habitus, field, and literacy instruction in a multilingual classroom. Language \& Literacy, 8(3), 1-26.

Hagevik, R, Aydeniz, M., \& Rowell, C. G. (2012). Using action research in middle level teacher education to evaluate and deepen reflective practice. Teaching and Teacher Education: An International Journal of Research and Studies, 28(5), 675-684.

Holter, A. C., \& Frabutt, J. M. (2012). Action research in Catholic schools: A step-by-step guide for practitioners $\left(2^{\text {nd }}\right.$ ed.). Alliance for Catholic Education Press.

Hopkins, D. A. (2008). Teacher's guide to classroom research (4th ed.). Open University Press.

Kitchen, J., \& Stevens, D. (2008). Action research in teacher education: Two teachereducators practice action research as they introduce action research to preservice teachers. Action Research, 6(1), 7-28

Kemmis, S., \& McTaggart, R. (1988). The action research planer. Deakin University Press.

Koshy, V. (2005). Action research for improving practice: A practical guide. Paul Chapman Publishing.

Lankshear, C., \& Knobel. M. (2004). A handbook for teacher research: From design to implementation. Open University Press.

Lather, P. (1992). Critical frames in educational research: Feminist and post-structural perspectives. Theory in Practice, 31(2), 87-99.

Limbrick, L., Buchanan, P., Goodwin, M., \& Schwarcz, H. (2010). Doing things differently: The Outcomes of teachers researching their own practice in teaching writing. Canadian Journal of Education, 33(4), 897-924.

Louis, K. S. (2008). Creating and sustaining professional communities. In A. Blankstein, P. Houston \& R. Cole (Eds.), Sustaining professional learning communities (pp. 41-57). Corwin.

Luttenber, J., Meijer, P., \& Oolbekkink-Marchand, H. (2017). Understanding the complexity of teacher reflection in action research. Educational Action Research, 25(1), 88-102. https://doi:10.1080/09650792.2015.1136230 
Margolis, J. (2002). Re-form-ing reflection (and action) in English education. English Education, 34(3), 136-214.

McCaffrey, J. R., Lockwood, D. F., Koretz, D. M., \& Hamilton, L. S. (2003). Evaluating value added models for teacher accountability [Monograph]. Santa Monica, CA: RAND Corporation. http://www.rand.org/pubs/monographs/2004/RAND_MG158.pdf

McNiff, J. (2002). Action research for professional development. Http://www. jeanmcniff.com/ar-booklet.asp

McNiff, J. (2013). Action research principles and practice ( $3^{\text {rd }}$ ed.). Routledge Taylor \& Francis Group.

Mezirow, J. (1981). A critical theory of adult learning and education. Adult Education, 21(1), $3-24$

Miles, M. B., \& Huberman, A. M. (1994). Qualitative data analysis (2nd ed.). Sage.

Mitchell, S. N., Reilly, R. C., \& Logue, M. E. (2009). Benefits of collaborative action research for the beginning teacher. Teaching and Teacher Education, 25(2), 344-349.

Moore, K. B. (2002). From children's services to children's spaces. Public provision, children and childhood. Routledge.

Navaneedhan, C. G. (2011). Reflective teaching pedagogy as innovative approach in teacher education through open and distance learning. Journal of Media and Communication Studies, 3(12), 331-335.

Ontario College of Teachers (OCT). (2016). Ontario College of Teachers' framework for the teaching profession. https://www.oct.ca/public/professional-standards/profess ional-learning-framework

Ontario College of Teachers (OCT). (2017). Accreditation resource guide. https://www.oct.ca/media/PDF/Accreditation\%20Resource\%20Guide/Accreditati on_Resource_Guide_EN_WEB.pdf

Ontario Ministry of Education (OME). (2014). 0. Reg. 347/02: Accreditation of teacher education programs. Ontario College of Teachers Act, 1996. https://www.ontario.ca/laws/regulation/020347

Ontario Ministry of Education (OME). (2020). Teacher learning and leadership program. http://edu.gov.on.ca/eng/teacher/tllp.html

Organization for Economic Co-operation and Development. (2018). OECD Future of education and skills 2030. https://www.oecd.org/education/2030-project/ 
Otto, C. A., Luera, G. R., \& Everett, S. A. (2009). An innovative course featuring action research integrated with unifying science themes. Journal of Science Teacher Education, 20(6), 537-552.

Pelton, R. P. (Ed.). (2010). Action research for teacher candidates using classroom data to enhance instruction. Rowman and Littlefield.

Perrett, G. (2003). Teacher development through action research: A case study in focused action research. Australian Journal of Teacher Education, 27(2), 1-10.

Phillips, D. K., \& Carr, K. (2009). Dilemmas of trustworthiness in preservice teacher action research. Action research, 7(2), 207-226.

Ponte, P., Beijard, D., \& Ax, J. (2004). Don't wait till the cows come home: Action research and initial teacher education in three different countries. Teachers and Teaching: Theory and Practice, 10(6), 591-621.

Putney, L. G., \& Broughton, S. (2010). Developing teacher efficacy through reflection: A Vygotskian perspective. Critical Issues in Teacher Education, XVII, 4-17.

Rivkin, S. G., Hanushek, E. A., \& Kain, J. F. (2005). Teachers, schools, and academic achievement. Econometrics, 73, 417-458.

Rowan, B., Correnti, R., \& Miller, R. J. (2002). What large scale survey research tells us about teacher effects on student achievement: Insights from the Prospects study of elementary schools. Teachers College Record, 104, 1525-1567.

Savaskan, I. P. (2013). Readiness for action research: Are teacher candidates ready to become an agent of action research? International Journal of Innovative Interdisciplinary Research, 2(12), 49-6

Schön, D. A. (1983). The reflective practitioner. Basic Books.

Schön, D. (1991). Educating the reflective practitioner. Jossey Bass.

Smith, K., \& Sela, O. (2005). Action research as a bridge between pre-service teacher education and in-service professional development. European Journal of Teacher Education, 28(3), 293-310.

Solheim, K., Ertesvåg, S.K., \& Berg, G. D. (2018). How teachers can improve their classroom interaction with students: New finding from teachers themselves. Journal of Educational Change, 19, 511-538.

Stringer, E. (2008). Action research in education. Pearson Education, Inc. 
Taylor, S. S., Rudolph, J. W., \& Foldy, E. G. (2008). Teaching reflective practice in the action science / action inquiry tradition: Key stages, concepts and practices. In P. Reason \& H. Bradbury (Eds.), The Sage Handbook of Action Research (2nd ed.) (pp. 656-668). Sage Publications.

Timperley, H. S., Parr, J. M., \& Bertanees, C. (2009). Promoting professional inquiry for improved outcomes for students in New Zealand. Professional Development in Education, 35(2), 227-245.

Ulvik, M. \& Riese, H. (2016). Action research in pre-service teacher education - A neverending story promoting professional development. Professional Development in Education, 42(3), 441-457.

Yin, R. K. (2014). Case study research: Design and methods (5 $5^{\text {th }}$ ed.). Sage.

Zambo, D. \& Zambo, R. (2007). Action research in an undergraduate teacher education program: What promises does it hold? Action in Teacher Education, 28(4), 62-74.

Zeichner, K. (2010). Rethinking the connections between campus courses and field experiences in college- and university-based teacher education. Journal of Teacher Education 61(1-2), 89-99.

\section{Biographical Note}

Glenda L. Black is an associate professor at the Schulich School of Education, Nipissing University. She has worked in the Canadian school system for over 20 years as a teacher, administrator, and teacher educator. Awarded numerous federal, provincial and national advocacy organizations, Glenda has researched and written extensively on teacher education. Her areas of interest are action research, Indigenous education, international teaching, and curriculum development. 